\title{
EMPLOYEE VOICE: AN EMPLOYEE SATISFACTION LEVEL BY SELECTED HEALTHCARE SERVICE PROVIDERS IN THE CZECH REPUBLIC
}

\author{
Jiří Bejtkovskýn \\ ${ }^{1}$ Department of Management and Marketing, Faculty of Management and Economics, Tomas Bata University in \\ Zlín, Mostní 5139, 76001 Zlín, Czech Republic
}

To cite this article: BEJTKOVSKÝ JIŘÍ. 2018. Employee Voice: an Employee Satisfaction Level by Selected Healthcare Service Providers in the Czech Republic. Acta Universitatis Agriculturae et Silviculturae Mendelianae Brunensis, 66(6): 1407-1416.

To link to this article: https://doi.org/10.11118/actaun201866061407

\begin{abstract}
The employee satisfaction level is closely related to the performance and quality of work performed by an employee and, consequently, it translates into the competitiveness and success of a corporation, because a motivated and satisfied employee builds and participates in the success of any corporation (organization, firm, hospital, etc.). The aim of the article was to discover more about the current situation employee satisfaction level by selected healthcare service providers in the context of the gender of employees and the length of current employment of the employees by selected healthcare service providers in the Czech Republic. The overall employee satisfaction level was monitored through seven selected research areas. The research was carried out in 2017 from the sample of 608 respondents. Two research hypotheses and one research question have been formulated. The verification or rejection of null research hypotheses was done through the statistical method of the Pearson's Chi-square test. The results came along with the discovery that there is a statistically significant relation between the overall employee satisfaction level by selected healthcare service providers and the gender of employees and there is no statistically significant relation between the overall employee satisfaction level by selected healthcare service providers and the length of current employment of the employees by selected healthcare service providers.
\end{abstract}

Keywords: Czech Republic, employee satisfaction level, gender, healthcare service provider, human resource management, loyalty, satisfaction and importance factors, survey

\section{INTRODUCTION}

The human resource management concept can be defined as an extensive field of scholarship involving different attitudes, procedures, and various levels of research works, studies and analyses (Wright and Boswell, 2002), as well as topics such as human resource management in creating significant benefits, possibilities and realization of corporate HR strategies (Lengnick-Hall et al., 2009).
According to Stacho et al. (2013), a formation of stimulating, motivating and very good corporate environment is a prerequisite for the efficient and active development of human resources management concept in today's corporations.

The employees are the most significant part of any corporation. The human resources are the workers of the work operations and activities. The employees contribute their work to the value of the products or services. The term human resources 
in corporation includes loyalty, stimulation, motivation, creativity, resistance to stress, skills, knowledge, abilities and other important qualities of employees in the corporation. The corporation's goals can be reaching by means of the emotional and intellectual verve of the human resources (Lepir et al., 2017).

Fajčíková and Urbancová (2017) state that the employees and their abilities, skills and knowledge represent the miscellaneous benefits and opportunities for corporations irrespective of the state or region in which corporations do business.

Regarding this, Su et al. (2017) mention that employees contribute to the sustainability of corporations or institution in many ways; and human governance is crucial in determining behavior and performance of employees - the employees are important in leading the corporation's success with a certain level of commitment and effort (Hanapiyah et al., 2017).

Prayogo, Adi Suryo Pranoto and Hardi Purba (2017) say that job satisfaction of human resources is one of the key variables having a beneficial effect on competitiveness and productivity of the corporations or institutions. A positive job satisfaction can increase engagement and creativity of staff. Human resources who are motivated and satisfied usually have higher job productivity, enthusiasm, and create interesting, new and effective solutions of problems. On the other hand, human resources who are dissatisfied and demotivated usually have lower job productivity, lower interest in job, co-workers, and corporation and can be disappointed with their job or corporation environment. For this reason, it is necessary that corporation regularly monitors the level of internal motivation and overall satisfaction of all its employees. For example, a classic questionnaire survey can be used. This questionnaire survey can use Likert's scale on different topics in the job conditions. It is important to infer the appropriate conclusions from the research and seek a compromise between the needs of the employees and the corporation.

According to Sypniewska (2014), a concept of job satisfaction is connected with various disciplines such as sociology, management, psychology or humanities. For example, in the field of sociology, it is a factor in dissimilar groups related to how a man assesses and perceives his job. In the area of psychology, the job satisfaction means a situation where a man has emotional perception of his situation and behaves cheerfully or sorrowfully. The job satisfaction depends on quality and performance of work carried out by man.

A goal of today's corporations is to employ the experienced and qualified human resources and subsequently to care for their job environment and their job satisfaction (Urbancová, Stachová and Stacho, 2015).

According to Sang-Bing (2018), personal elements and corporation environment can positively or negatively affect job satisfaction. The personal elements can represent for example personality traits, cognitive and professional abilities, expectations or demographic attributes and so on. The corporation environment can constitute for example working conditions, relationships between colleagues and superiors, work safety, job rank or compensation policies etcetera. A high level of employee satisfaction can lead to low fluctuation and low absenteeism in the corporation or institution. On the other hand, a low level of employee satisfaction can lead to high fluctuation and high absenteeism in the corporation or institution.

The main objective of this research article is to discover more about the current situation employee satisfaction level by selected healthcare service providers in the context of the gender of employees and the length of current employment of the employees by selected healthcare service providers in the Czech Republic. The overall level of employee satisfaction will be monitored through seven selected research areas.

\section{Employees and their job satisfaction at work}

Rastgoo (2016) says the employees are assets of a society and corporation - the fundamentals of every corporation or organization are the human resources and there is no doubt in its importance.

Because human resources, employees, are perceived as an indispensable corporate asset, managers must maintain and improve employee job satisfaction, retain competent employees, improve the corporation's overall work efficiency, appoint suitable staff to suitable positions, and stimulate employees to their full potential (Sang-Bing, 2018).

Regarding this, Jun, Yuyan, Yao and Zhixue (2017) declare that employees are the essential part of a corporation, their satisfaction determines whether corporations and employees can keep a harmonious sustainable development trend or not.

Suttikun, Chang and Bicksler (2018) assert that being that staff productivity is a main and primary factor driving the competitiveness and success of a corporation or organization, it is important to understand how employees are motivated, engaged, and retained at the work place.

It is also clearly established by many researchers that a satisfied worker or employee would be a real productive one. In this age of tough global competition, it becomes imperative for organizations to achieve higher levels of productivity and to outsmart the competitors (Rajasekar, Krishna Sudheer and Raghunadha Reddy, 2017).

Staw (1984) claims that a job satisfaction of staff is a frequently studied dependent variable in communication research in corporation - in the workplace.

Noe, Hollenbeck, Gerhart and Wright (2007) determine job satisfaction as a pleasant feeling as a result of the perception that the work meets the values important work. 
Regarding this, Locke (1976) defines job satisfaction as a pleasurable or positive emotional state resulting from the appraisal of one's job or job experiences.

Employees who are more satisfied with their daily work are more likely to help corporations reach their tasks and goals efficiently (Scott and Stephens, 2009). In other words, job satisfaction can reap positive benefits within workplace tasks, roles, and relationships. Organizational research has generally viewed job satisfaction as a variable that is created internally through workplace interactions, practices, routines, and policies (Robertson and Kee, 2017).

Aliff Abdul Majid et al. (2017) say that employee's job satisfaction plays a major role in organizational performance.

According to De Simone, Planta and Cicotto (2018), job satisfaction is associated with greater work activity, motivation, loyalty, work engagement, occupational health and best job performance among employees.

\section{Employees in healthcare organisations}

In recent years, public hospitals have had to cope with numerous challenges including increasing competition and the rapid increase of demand in terms of quantity and quality (Zweifel, 2016).

The financial cutbacks in public funding and the increasing number of patients have highlighted the urgency to improve the quality of service in healthcare, qualification and job satisfaction of staff and, at the same time, to reduce the costs of healthcare (Aiken, Clarke and Sloane, 2002).

According to Hayes et al. (2012), in an era of resource limitations, healthcare effectiveness is a significant goal that is hampered by the global nurse shortage and high turnover.

To achieve the goal of continuous improvement of care and healthcare service quality, healthcare organisations must constantly monitor and promote the health, motivation and satisfaction of all the employees who are involved in the healthcare process (Al-Abri and Al-Balushi, 2014).

Regarding this, Giles, Parker, Mitchell and Conway (2017) claim that understanding what job characteristics influence job satisfaction is vital if healthcare organizations are to optimize individual employee satisfaction and performance.

The concept of job satisfaction is important for employees in healthcare organisations to improve not only nurses' retention and patient satisfaction.
Satisfied employees in healthcare organisations tend to be more productive and creative to their organizations. Recent studies have shown a direct correlation between staff satisfaction, organizational commitment and patient satisfaction in healthcare organizations (Alotaibi, Paliadelis, Valenzuela, 2015; Alsaraireh, Quinn Griffin, Ziehm and Fitzpatrick, 2014; Delobelle et al., 2011; Kuo, Lin and Li, 2014).

Spector (1985) defines job satisfaction as the degree of positive or negative feelings towards one's job. Spector (1985) has proposed nine facets for measuring job satisfaction, including pay, promotion, supervision, fringe benefits, contingent rewards, operating procedures, co-workers relationship, nature of work and communication.

\section{MATERIALS AND METHODS}

The paper deals with human resource management - employee satisfaction level - by selected healthcare service providers in the Olomouc Region and Zlín Region.

The purpose of the submitted article was to discover more about the current situation of the employee satisfaction level by selected healthcare service providers in the context of the gender of employees and the length of current employment of the employees by selected healthcare service providers in the Czech Republic.

The selected regions of the Czech Republic were chosen on the basis of sameness in macroeconomic indicators. The structure of the selected regions is shown in the following Tab. 1.

The Tab. 1 presents the structure of the selected regions according to macroeconomic indicators. The selected healthcare service providers were compared by number of beds. Both healthcare service providers are classified as big hospital, i.e. The capacity of beds is of more than five hundred units.

For the aim of following the defined goal, primary and secondary information sources were used and analyzed. The baseline secondary data were obtained both from professional monographs and by analysis of research literature available in electronic databases (especially including articles presented by the Scopus and Web of Science databases).

On the basis of literary research, analysis and evaluation of the information and facts gained, there were two research hypotheses ( $\mathrm{H} 1, \mathrm{H} 2)$ and one research question (RQ1) formulated:

I: The structure of the selected regions according to macroeconomic indicators

\begin{tabular}{lcc}
\hline \multicolumn{1}{c}{ Macroeconomic Indicator } & Olomouc Region & Zlín Region \\
\hline Population (total) & 633157 & 583093 \\
Gross domestic product (CZK million) & 215650 & 222918 \\
Unemployment rate & $4.35 \%$ & $3.43 \%$ \\
Average gross monthly wage (CZK) & 25599 & 25273 \\
\hline
\end{tabular}

Source: czso.cz, (C2018 
$\mathrm{Hl}$ : There is a statistically significant relation between the overall employee satisfaction level by selected healthcare service providers and the gender of employees by selected healthcare service providers.

$\mathrm{H} 2$ : There is a statistically significant relation between the overall employee satisfaction level by selected healthcare service providers and the length of current employment of the employees by selected healthcare service providers.

RQ1: Which research area (a part of overall employee satisfaction level) will be assessed by respondents according to importance as the most important?

Primary data were collected via qualitative and quantitative marketing research. Some of the results are presented in this contribution.

Qualitative marketing research was carried out in 2017 (in January) through semi-structured interviews with selected employees by selected healthcare service providers in the Olomouc Region and Zlín Region. The aim of the semi-structured interviews was to explore and then to analyze the key areas of employee satisfaction level by selected healthcare service providers. Then quantitative research followed. Quantitative marketing research was realized via an anonymous questionnaire survey. The structured questionnaires were available both in printed and electronic format and distributed among employees by selected healthcare service providers in the Olomouc Region and Zlín Region. In February 2017, a pretest of the structured questionnaire was also carried out. The pretest of the structured questionnaire was performed on a sample of twenty respondents.

The main research was conducted on the basis of an evaluation of the results. This research was carried out from March to November 2017.

Because seventeen of the questionnaires received were not filled in properly, they had to be excluded from the evaluation. Nevertheless, the final range of the sampling frame, which served for purposes of mathematical statistics-related evaluation of research hypotheses, comprised six hundred and eight filled-in structured questionnaires (of which three hundred twenty-two respondents were from the Olomouc Region and two hundred and eighty-six respondents were from the Zlín Region) from employees by selected healthcare service providers. The verification of the proposed research hypotheses was performed by the Pearson's statistical method of Chi-square test. Chi-square test is based on the dependence measurement. This is the test that detects whether there is the dependence between statistical characters. That means that the occurrence of certain character values A can assume probability of occurrence of certain character values B. If the $\mathrm{P}$-value is lower than the chosen significance level (typically $5 \%$, i.e. 0.05), the zero hypothesis is rejected - the difference between the abnormalities found in the sample and the expected abundances is too large to be the result of random selection, i.e. it is statistically significant.

The analysis was carried out using Microsoft Excel 2013 and the statistical software IBM SPSS Statistics 23.

The structured questionnaire was divided into eight parts. The structured questionnaire was focused not only on the employee satisfaction level, but also on the importance of factors and variables. The research areas were: (1) job satisfaction, (2) communication and information sharing, (3) interpersonal relationships at the workplace, (4) professional development and career growth, (5) remuneration and evaluation, stimulation and motivation, (6) relationships with employer - healthcare service provider, (7) safety and health protection of employees at work.

The first seven parts of the structured questionnaire were aimed at determining the employee satisfaction level and importance for employee. The respondents used the 4-point Likert-type scale (from 1 = strongly dissatisfaction, strongly irrelevance to 4 = strongly satisfaction, strongly importance) to respond to the scale items in this measure. The last part of the structured questionnaire served to identify the respondents.

The results of both marketing research parts (qualitative and quantitative research) were used for answering the formulated research question.

To process both secondary and primary information resources and to phrase the conclusions, selected scientific methods were used, including analysis, synthesis, induction and deduction.

\section{Characteristics of respondents sample}

The quantitative marketing research involved 608 respondents (employees of selected healthcare service providers in the Olomouc Region and Zlín Region). The respondents were classified on the basis of the following criteria - identification data in structured questionnaire: (1) region of the Czech Republic, (2) gender of respondents, (3)

II: The structure of the addressed employees working in the selected healthcare service providers

\begin{tabular}{lclc}
\hline Region of the Czech Republic & Number of respondents & Gender of respondents & Number of respondents \\
\hline \multirow{2}{*}{ Olomouc } & 322 & Female & 269 \\
\multirow{2}{*}{ Zlín } & \multirow{2}{*}{286} & Male & 53 \\
& & Female & 248 \\
\hline
\end{tabular}

Source: Authors, own survey 
biological age of respondents and (4) the length of current employment of the employees by selected healthcare service providers.

The structure of the addressed employees working in the selected healthcare service providers is shown in the tables below Tab. II and Tab. III.

The Tab. II presents the structure of the addressed employees working in the selected healthcare service providers according to region and gender.

The Tab. III presents the structure of the addressed employees working in the selected healthcare service providers according to age and length of current employment of the employees by selected healthcare service providers.

\section{RESULTS}

This chapter presents the results of a research conducted with selected healthcare service providers in the Olomouc Region and Zlín Region. Two research hypotheses $(\mathrm{H} 1, \mathrm{H} 2)$ and one research question (RQ1) were formulated.

HO: There is no correlation between the overall employee satisfaction level by selected healthcare service providers and the gender of employees by selected healthcare service providers.

HA: There is correlation between the overall employee satisfaction level by selected healthcare service providers and the gender of employees by selected healthcare service providers.

The Tab. Tab. IV shows data that characterize the research hypothesis $\mathrm{Hl}$.
When considering a dependence of the relation between the overall employee satisfaction level by selected healthcare service providers and the gender of employees by selected healthcare service providers, the $\mathrm{p}$-value of Pearson's Chi-square test of independence is lower than the defined level of significance (0.05).

The result of a verification of the research hypothesis shows that the null hypothesis (HO) of independence was therefore rejected at a level of independence of $5 \%$. The $\mathrm{Hl}$ hypothesis was therefore not rejected.

The Hl hypothesis - there is a statistically significant relation between the overall employee satisfaction level by selected healthcare service providers and the gender of employees by selected healthcare service providers - was therefore confirmed. According to Cramer's V, it can be concluded that a relation is considered as weak (small).

HO: There is no correlation between the overall employee satisfaction level by selected healthcare service providers and the length of current employment of the employees by selected healthcare service providers.

HA: There is correlation between the overall employee satisfaction level by selected healthcare service providers and the length of current employment of the employees by selected healthcare service providers.

The Tab. IV shows data that characterize the research hypothesis $\mathrm{H} 2$.

III: The structure of the addressed employees working in the selected healthcare service providers

\begin{tabular}{cccccc}
\hline $\begin{array}{c}\text { Biological age of } \\
\text { respondents }\end{array}$ & $\begin{array}{c}\text { Number of } \\
\text { respondents (n) }\end{array}$ & $\begin{array}{c}\text { The relative } \\
\text { frequency }\end{array}$ & $\begin{array}{c}\text { Length of current } \\
\text { employment }\end{array}$ & $\begin{array}{c}\text { Number of } \\
\text { respondents (n) }\end{array}$ & $\begin{array}{c}\text { The relative } \\
\text { frequency }\end{array}$ \\
\hline up to 20 years & 17 & $2.80 \%$ & up to l year & 4 & $0.66 \%$ \\
\hline $21-30$ & 63 & $10.36 \%$ & $1-3$ & 32 & $5.26 \%$ \\
\hline $31-40$ & 214 & $35.20 \%$ & $4-7$ & 239 & $39.30 \%$ \\
\hline $41-50$ & 201 & $33.05 \%$ & $8-12$ & 104 & $17.11 \%$ \\
\hline $51-60$ & 80 & $13.16 \%$ & 13 years and over & 229 & $37.67 \%$ \\
\hline 61 years and over & 33 & $5.43 \%$ & Total & 608 & $100.00 \%$ \\
\hline Total & 608 & $100.00 \%$ & & & \\
\hline
\end{tabular}

Source: Authors, own survey

IV: The verification of the research hypotheses $H 1$ and $H 2$ by means of the Pearson's Chi-square test

\begin{tabular}{|c|c|c|c|}
\hline \multicolumn{4}{|c|}{$\begin{array}{l}\text { H1: There is a statistically significant relation between the overall employee satisfaction level by selected } \\
\text { healthcare service providers and the gender of employees by selected healthcare service providers. }\end{array}$} \\
\hline The statistical method & Chi-square & Df & p-value \\
\hline Cramer's V & .120 & $\begin{array}{c}\text { Statistical } \\
\text { Interpretation }\end{array}$ & weak/small \\
\hline \multicolumn{4}{|c|}{$\begin{array}{c}\text { H2: There is a statistically significant relation between the overall employee satisfaction level by selected } \\
\text { healthcare service providers and the length of current employment of the employees by selected healthcare } \\
\text { service providers. }\end{array}$} \\
\hline The statistical method & Chi-square & df & p-value \\
\hline Pearson's Chi-square test & 14.985 & 12 & .242 \\
\hline
\end{tabular}

Source: Authors, own survey, own processing at SPSS Statistics program 23 (2018) 
The result of verification of the research hypothesis shows that the p-value of Pearson's Chi-square test of independence is 0.242 . The result of its validity verification indicates that the $p$-value of the Pearson 's Chi-square test of independence is higher than the specified limit value of 0.05. Thus, the HO hypothesis is not rejected on the significance level of $5 \%$.

In this case, it can be concluded that there is no statistically significant relation between the overall employee satisfaction level by selected healthcare service providers and the length of current employment of the employees by selected healthcare service providers.

The research question 1 (RQ1): Which research area (a part of overall employee satisfaction level) will be assessed by respondents according to importance as the most important?

The addressed respondents identified research areas (a part of overall employee satisfaction level) according to importance as follows: (1) interpersonal relationships at the workplace, (2) job satisfaction, (3) communication and information sharing, (4) remuneration and evaluation, stimulation and motivation, (5) professional development and career growth, (6) relationships with employer - healthcare service provider, (7) safety and health protection of employees at work.

The Tab. V presents identified research areas (a part of overall employee satisfaction level) according to satisfaction and importance for employees (for human resources).

According to Tab. V, the interpersonal relationships at the workplace have become the most important research area (a part of overall employee satisfaction level). A mean of this research area was 3.6234 (according to importance); the standard deviation value for this research area was 0.7178 . The job satisfaction was on the second place. A mean of this research area was 3.6036 (according to importance); the standard deviation value for this research area was 0.8152 . The safety and health protection of employees at work were on the last place. A mean of this research area was 3.4062 (according to importance); the standard deviation value for this research area was 1.0305 .
It is obvious that interpersonal relationships are very important, not only at the workplace. Kindly and friendly relationships between employees should be comprised of a few major qualities, namely empathy, trust, effective and ease of communication, respect and willingness to help. Further, it can be said that most of the addressed respondents - employees - were satisfied by selected healthcare service providers.

\section{DISCUSSION}

Undoubtedly, employee satisfaction level is the most important factor that increases the efficiency of the workforce.

In this context, findings by Dobre (2013), who researched motivation and stimulation of human resources in corporations depending on their performance, are very attractive. Dobre (2013) said that a motivated and educated man is indispensable for corporations that want to be efficient, productive and increase satisfaction not only of their human resources but also purchasers or consumers.

In research literature, an employee satisfaction level is described with favorable impacts on employee's work, on colleagues and on corporations (firms, institutions, hospitals, etc.). It is possible to expect that satisfied and motivated employees participate in existence and prosperity of their corporation. According to researchers, a satisfaction of human resources in corporations is perceived in a large number of levels (Sypniewska, 2014).

Garg et al. (2018) assert, according to their research, that satisfied human resources are more interested in their corporation than those who are not satisfied in their corporation. They found also that the correlation between employee engagement and employee satisfaction evinces a positively mild character.

The research discoveries of Urbancová and Šnýdrová (2017) have proved that employee benefits are created and offered effectively and correctly in corporations. The examined employee benefits may differentiate corporations from their competitors in the business environment and may increase employee satisfaction and loyalty of employees.

V: Identified research areas (a part of overall employee satisfaction level) according to satisfaction and importance for employees

\begin{tabular}{lcccc}
\hline \multicolumn{1}{c}{ Research areas } & $\begin{array}{c}\text { Satisfaction } \\
(\mathbf{n = 6 0 8})-\text { mean }\end{array}$ & $\begin{array}{c}\text { Std. } \\
\text { Deviation }\end{array}$ & $\begin{array}{c}\text { Importance } \\
(\mathbf{n}=\mathbf{6 0 8}) \text {-mean }\end{array}$ & $\begin{array}{c}\text { Std. } \\
\text { Deviation }\end{array}$ \\
\hline Interpersonal relationships at the workplace & 3.6908 & .6838 & 3.6234 & .7178 \\
\hline Job satisfaction & 3.6628 & .7282 & 3.6036 & .8152 \\
\hline Communication and information sharing & 3.8010 & .5579 & 3.5921 & .7958 \\
\hline Remuneration and evaluation, stimulation and motivation & 3.5691 & .8048 & 3.5806 & .8246 \\
\hline Professional development and career growth & 3.6875 & .7154 & 3.4826 & .8646 \\
\hline Relationships with employer - healthcare service provider & 3.6727 & .7394 & 3.4227 & .9539 \\
\hline Safety and health protection of employees at work & 3.9326 & .3636 & 3.4062 & 1.0305 \\
\hline
\end{tabular}

Source: Authors, own survey 
In this paper, it was mainly undertaken to investigate on the current situation of the employee satisfaction level by selected healthcare service providers in the context of the gender of employees and the length of current employment of the employees by selected healthcare service providers in the Czech Republic.

Alghamdi et al. (2017) investigated the fundamental impacts on the nurse's gender, manager's gender, the interaction term on satisfaction with the work of the nurses and the perception of the manager's leadership style. Their researches showed a significant impact on the gender of the manager on both satisfaction with the work and perception of the manager's leadership style ( $p<0.05$ ) without important influence of the nurse's gender and interaction term on these factors.

The research results of this article provide relatively strong support for the existence of a significant relation between the overall employee satisfaction level by selected healthcare service providers and the gender of employees by selected healthcare service providers. The results of this contribution also show that there is no significant relation between the overall employee satisfaction level by selected healthcare service providers and the length of current employment of the employees by selected healthcare service providers.

According to Ariza-Montes, Arjona-Fuentesa, Han and Law (2018), the relationship and correlation between life satisfaction and job satisfaction evokes a wide attention from various fields, such as psychology, economics, management, sociology, administration and so on.

Regarding this, Suliman and Aljezawi (2018) say that their discoveries suggest a positive and powerful correlation between the job environment of nurses and job satisfaction of nurses in hospitals. The nurses with a higher biological age and with smaller professional qualifications are more satisfied in hospitals.

According to Giles et al. (2017), a satisfaction of the employees with their work was defined as strong (mean 4.3) and is significantly associated with role clarity, job support, job autonomy and conflict of roles. The strong degree of role clarity has smaller impact on the relationship between work autonomy and satisfaction of the employees with their work.

The research results of Sypniewska (2014) have shown that there are many statistically significant relation between the importance characterized to individual variables and the overall rate of satisfaction of the employees with their work, especially regarding the selection based on the groups of the respondents from the analysis.

The research results of Shen (2010) emerge that while a rate of employees' satisfaction (in the private sector) with remuneration evaluation, recruitment process and work performance of staff was between high and medium value, so a rate of satisfaction with development and education of human resources was at a low value. The rate of employee satisfaction with human resource management was different on the basis of work position, education, working years, loyalty, age, registration status and gender.

Nurses' ages were explored in Labraguea et al., (2018) research. The age classes of nurses were found to considerably impact on their loyalty to the hospital. The satisfaction of the nurses with their work $(p=0.001)$ and job stress $(p=0.001)$ powerfully prognosticated turnover intentions in the nurses. The mean variables for scale of the satisfaction of the nurses with their work, for scale of job stress, and for scale of turnover intention inventory were $3.13,2.74$, and 2.43 respectively.

The entire research was mainly divided into different headings such as job satisfaction, communication and information sharing, interpersonal relationships at the workplace, professional development and career growth, remuneration and evaluation, stimulation and motivation, relationships with employer - healthcare service provider and safety and health protection of employees at work. Each research area has been divided into different criteria, in which it has been investigated about the existence of employee satisfaction level.

According to Trel'ová and Olšavský (2017), the overall level of satisfaction of the human resources with their work presents a sum of a few smaller satisfactions. A familiarity with variables which influence motivation and satisfaction of the employees with their work enables to define and elaborate an effective and high-performance motivational program of corporation. This motivational program can have some effect on the behaviour of an employee or the employees.

According to Pauceanu, Sanyal and Wamique Hisam (2016) and their findings of the study reveal that there is an important impact between the satisfaction of the workforce and the quality of work dimensions. In particular, factors like availability of tools and resources, encouragement to come up with innovative ideas at work, diversity at the workplace, well defined goals, feeling of accomplishment at work, the work environment and opportunities for promotion and career growth have a significant contribution towards the employee satisfaction level at work.

Employee satisfaction level is one of the important factors not only of the hospital to enhance the loyalty, productivity and motivation of employee. Successful combination of two factors (finance and non-finance) is the outcome of proper employee satisfaction level. Management role is also considered as an important factor that gives proper employee satisfaction level and increases not only hospital competitiveness (Chatterjee and Priya, 2016).

In context of the competitive environment, Vydrová (2012) says that information and knowledge sharing corporations are one of the most successful corporations in today's competitive environment. 


\section{CONCLUSION}

Employee satisfaction level seems to be an interesting and beneficial topic not only for hospital management. Therefore, this area should not be underestimated. A satisfied employee is a valuable resourcethataffectsthe performance,efficiency, and competitiveness of the corporation-organization, firm, hospital, etc.

The main goal of the contribution was to discover more about the current situation employee satisfaction level by selected healthcare service providers in the context of (1) the gender of employees and (2) the length of current employment of the employees by selected healthcare service providers in the Czech Republic. The overall employee satisfaction level was monitored through seven selected research areas.

The research findings have found that there is a statistically significant relation between the overall employee satisfaction level by selected healthcare service providers and the gender of employees and there is no statistically significant relation between the overall employee satisfaction level by selected healthcare service providers and the length of current employment of the employees by selected healthcare service providers.

It was also examined which research area (a part of overall employee satisfaction level) will be assessed by respondents according to importance as the most important. The interpersonal relationships at the workplace have become the most important research area (a part of overall employee satisfaction level). It is understandable that the interpersonal relationships at the workplace affect all areas at human work.

A benefit and a significance of this research paper lie in discovery of the current situation employee satisfaction level by selected healthcare service providers in the context of the gender of employees and the length of current employment of the employees by selected healthcare service providers in the Czech Republic.

In this study, there are certain limits; (1) it does not distinguish the job position of the employees at selected healthcare service providers in the Czech Republic (the different factors can play a significant role for physicians, different for nurses and other staff at selected healthcare service providers); (2) it does not distinguish the biological age of the respondents at selected healthcare service providers; (3) the selected healthcare service providers are only in the Czech Republic; (4) the research was carried out only at healthcare service providers; (5) the research was performed only in two regions in the Czech Republic. Despite these limits, the research offers interesting and new discoveries in this research area.

In the future research, (1) the research purpose can be extended to the job position and biological age of the respondents at selected healthcare service providers; (2) the research purpose can be extended to the healthcare service providers in the whole Czech Republic; (3) the employee satisfaction level can be investigated at selected healthcare service providers in other countries and then compared; (4) other factors directly affecting the employee satisfaction level can be further explored; (5) to analyse reward practices how it moves away from shareholder-value reward to stakeholder reward, making full use of employee voice mechanisms as a key ingredient of workplace innovation.

\section{REFERENCES}

AIKEN, L. H., CLARKE, S. P. and SLOANE, D. M. 2002. Hospital staffing, organization, and quality of care: Cross-national findings. Nursing Outlook, 50(05): 187-194.

AL-ABRI, R. and AL-BALUSHI, A. 2014. Patient satisfaction survey as a tool towards quality improvement. Oman Medical Journal, 29(01): 03-07.

ALGHAMDI, M. G., TOPP, R. and ALYAMI, M. S. 2017. The effect of gender on transformational leadership and job satisfaction among Saudi nurses. Journal of Advanced Nursing, 74(01): 119-127.

ALIFF ABDUL MAJID, M., OTHMAN, M., FATIMAH MOHAMAD, S. and ABDUL HALIM LIM, S. 2017. Employee Satisfaction with Offshore Catering Job: Piloting for Interviews. International Journal of Academic Research in Business and Social Sciences, 07(10): 729-737.

ALOTAIBI, J., PALIADELIS, P. S. and VALENZUELA, F. R. 2015. Factors that affect the job satisfaction of Saudi Arabian nurses. Journal of Nursing Management, 24(03): 275-282.

ALSARAIREH, F., QUINN GRIFFIN, M. T., ZIEHM, S. R. and FITZPATRICK, J. J. 2014. Job satisfaction and turnover intention among Jordanian nurses in psychiatric units. International Journal of Mental Health Nursing, 23(05): 460-467.

ARIZA-MONTES, A., ARJONA-FUENTESA, J. M., HAN, H. and LAW, R. 2018. The price of success: A study on chefs' subjective well-being, job satisfaction, and human values. International Journal of Hospitality Management, 69(01): 84-93.

ČESKÝ STATISTICKÝ ÚŘAD. 2018. Český statistický úřad | ČSÚ. [Online]. Available at: http://www.czso. cz/ [Accessed: 20th January 2018]. 
DE SIMONE, S., PLANTA, A. and CICOTTO, G. 2018. The role of job satisfaction, work engagement, selfefficacy and agentic capacities on nurses' turnover intention and patient satisfaction. Applied Nursing Research, 39(01): 130-140.

DELOBELLE, P., RAWLINSON, J. L., NTULI, S., MALATSI, I., DECOCK, R. and DEPOORTER, A. M. 2011. Job satisfaction and turnover intent of primary healthcare nurses in rural South Africa: A questionnaire survey. Journal of Advanced Nursing, 67(02): 371-383.

DOBRE, O. I. 2013. Employee motivation and organizational performance. Review of Applied Socio-Economic Research, 05(01): 53.

FAJČÍKOVÁ, A. and URBANCOVÁ, H. 2017. The Role of Organizations in Lifelong Learning and Development. Acta Universitatis Agriculturae et Silviculturae Mendelianae Brunensis, 65(02): 621-630.

GARG, K., AHMAD DAR, I. and MISHRA, M. 2018. Job Satisfaction and Work Engagement: A Study Using Private Sector Bank Managers. Advances in Developing Human Resources, 20(01): 58-71.

GILES, M., PARKER, V., MITCHELL, R. and CONWAY, J. 2017. How do nurse consultant job characteristics impact on job satisfaction? An Australian quantitative study. BMC Nursing, 16(01): 01-10.

HANAPIYAH, Z. M., DAUD, S., WAN ABDULLAH, W. M. T. and ZAINOL, Z. 2017. Human governance and employee compensation: A conceptual framework. Advanced Science Letters, 23(09): 8718-8722.

HAYES, L. J., O'BRIEN-PALLAS, L., DUFFIELD, CH., SHAMIAN, J., BUCHAN, J. M., HUGHES, F., LASCHINGER, H. and NORTH, N. 2012. Nurse turnover: A literature review - An update. International Journal of Nursing Studies, 49(07): 887-905.

CHATTERJEE, S. and PRIYA, S. 2016. Employee Satisfaction Level - A Study on Multispecialty Hospital. International Journal of Emerging Trends $\sigma$ Technology in Computer Science, 03(12): 4910-4918.

JUN, W., YUYAN, L., YAO, C. and ZHIXUE, L. 2017. Employee satisfaction assessment from the perspective of demand side-based on G1-FUZZY-DSS. Journal of Discrete Mathematical Sciences and Cryptography, 20(04): 781-792.

KUO, H. T., LIN, K. C. and LI, I. C. 2014. The mediating effects of job satisfaction on turnover intention for long-term care nurses in Taiwan. Journal of Nursing Management, 22(02): 225-233.

LABRAGUEA, L. J., GLOE, D., MCENROE, D. M., KONSTANTINOS, K., COLET, P. 2018. Factors influencing turnover intention among registered nurses in Samar Philippines. Applied Nursing Research, 39(01): $200-206$.

LENGNICK-HALL, M. L., LENGNICK-HALL, C. A., ANDRADE, L. S. and DRAKE, B. 2009. Strategic human resource management: The evolution of the field. Human Resource Management Review, 19(02): 64-85.

LEPIR, L., ŠĆEPOVIĆ, D. and RADONJIĆ, A. R. 2017. Challenges of human resource management in the institutions for care of elderly people. In: IOP Conference Series: Materials Science and Engineering. Vol. 200. IOP Publishing Ltd.

LOCKE, E. A. 1976. The nature and causes of job satisfaction. In: DUNNETTE, M. D. (Ed.), Handbook of industrial and organizational psychology. ${ }^{\text {st }}$ Edition. Chicago: Rand McNally College.

NOE, R. A., HOLLENBECK, J. R., GERHART, B. and WRIGHT, P. M. 2007. Fundamentals of human resource management. $2^{\text {nd }}$ Edition. New York: McGraw-Hill/Irwin.

PAUCEANU, A. M., SANYAL, S. and WAMIQUE HISAM, M. 2016. Variables affecting employee satisfaction evidence from sultanate of Oman. International journal of applied business and economic research, 14(01): 499-510.

PRAYOGO, L., ADI SURYO PRANOTO, B. and HARDI PURBA, H. 2017. Employee satisfaction analysis with human resource index. Management Science Letters, 07(01): 233-240.

RAJASEKAR, D., KRISHNA SUDHEER, A. and RAGHUNADHA REDDY, P. 2017. A study on employee empowerment in Indian corporate sector. International Journal of Civil Engineering and Technology, 08(11): 268-277.

RASTGOO, P. 2016. The Role of Human Resources Competency in Improving the Manager Performance. Acta Universitatis Agriculturae et Silviculturae Mendelianae Brunensis, 64(01): 341-350.

ROBERTSON, B. W. and KEE, K. F. 2017. Social media at work: The roles of job satisfaction, employment status, and Facebook use with co-workers. Computers in Human Behavior, 70(01): 191-196.

SANG-BING, T.2018. Using the DEMATELmodel to explore the job satisfaction of research and development professionals in china's photovoltaic cell industry. Renewable and Sustainable Energy Reviews, 81(01): $62-68$.

SCOTT, C. R. and STEPHENS, K. K. 2009. It depends on who you're talking to ...:Predictors and outcomes of situated measures of organizational identification. Western Journal of Communication, 73(01): 370-394.

SHEN, J. 2010. Employees' satisfaction with HRM in Chinese privately-owned enterprises. Asia Pacific Business Review, 16(03): 339-354.

SPECTOR, P. E. 1985. Measurement of human service staff satisfaction: Development of the job satisfaction survey. American Journal of Community Psychology, 13(06): 693-713.

SULIMAN, M. and ALJEZAWI, M. 2018. Nurses' work environment: Indicators of satisfaction. Journal of Nursing Management, 26(5): 525-530.

STACHO,Z., URBANCOVÁ, H. and STACHOVÁ, K. 2013. Organisational arrangement of human resources management in organisations operating in Slovakia and Czech Republic. Acta Universitatis Agriculturae et Silviculturae Mendelianae Brunensis, 61(07): 2787-2799. 
STAW, B. M. 1984. Organizational behavior: A review and reformulation of the field's outcome variables. Annual Review of Psychology, 35(01): 627-666.

SU, X., LIU, Y. and HANSON-RASMUSSEN, N. 2017. Voice Behavior, Supervisor Attribution and Employee Performance Appraisal. Sustainability, 09(10): 1829.

SUTTIKUN, C., CHANG, H. J. and BICKSLER, H. 2018. A qualitative exploration of day spa therapists' work motivations and job satisfaction. Journal of Hospitality and Tourism Management, 34(01): 01-10.

SYPNIEWSKA, B. 2014. Evaluation of Factors Influencing Job Satisfaction. Contemporary Economics, 08(01): $57-72$.

TREL'OVÁ, S. and OLŠAVSKÝ, F. 2017. Employee Satisfaction with Training Opportunities and its Relation to Internal Marketing. Holistica, 08(02): 07-16.

URBANCOVÁ, H., STACHOVÁ, K. and STACHO, Z. 2015. Methods of Recruitment in the Czech and Slovak Organizations. Acta Universitatis Agriculturae et Silviculturae Mendelianae Brunensis, 63(03): 1051-1060.

URBANCOVÁ, H. and ŠNÝDROVÁ, M. 2017. Remuneration and Employee Benefits in Organizations in the Czech Republic. Acta Universitatis Agriculturae et Silviculturae Mendelianae Brunensis, 65(01): 0357-0368.

VYDROVÁ, J. 2012. The Role of Knowledge Workers and Company Culture in a Successful KnowledgeSharing Organisation. In: Innovation Vision 2020: Sustainable Growth, Entrepreneurship, and Economic Development. Proceedings of the 19th International Business Information Management Association Conference, pp. 2052-2061.

WRIGHT, P. M. and BOSWELL, W. R. 2002. Desegregating HRM: a review and synthesis of micro and macro human resource management research. Journal of Management, 28(03): 247-276.

ZWEIFEL, P. 2016. A novel way to compare health care systems and to assess their potential competitiveness. Economic Affairs, 36(02): 155-167. 